New Zealand Journal of Industrial Relations, 1992, 17, 39-55

\title{
Unions and Industrial Relations in Papua New Guinea
}

\author{
Michael Hess and James Gissua *
}

When Papua New Guinea became independent in 1975, it inherited the Australian system of compulsory conciliation and arbitration from its former colonial rulers. This system with the central reality it ascribes to trade unions as the industrial representatives of workers has been under considerable attack in both Australia and New Zealand in recent years. In Papua New Guinea too its effectiveness has not gone unquestioned. This paper seeks first to provide some background to understandirg the evolution of Papua New Guinea's industrial relations system and then looks in detail at some recent examples of its operation.

\section{The historical background}

In the early 1960 s the Australian colonial Administration of the Territory of Papua and New Guinea (TPNG), as it was then, legislated for the introduction of a system of compulsory conciliation and arbitration. It did so against a background of 60 years of paternalistic over-regulation of labour, in which only the Rabaul Strike of 1929 stands out as a direct challenge to employer and state authority (Gammage, 1975; Willis, 1970). Individual protest against conditions of work had, however, not been uncommon and the Administration's paternalistic approach had inhibited the growth of a free labour market. The result was "a perpetual condition of labour crisis" (Rowley, 1958, p.524), in which Administration policy concentrated on the highly regulated plantation sector. Even in this area there was too little labour available and in the growing urban labour markets workers lacked the skills and commitment to successfully partner foreign capital in the tasks of economic development (Hess, 1983).

Eventually it was the collective action of Port Moresby's workers which precipitated a reappraisal of government policy (Hess, 1982, p.50ff). Motivated by considerations of international and Australian domestic politics, the Minister for Territories, Paul Hasluck, chose to ignore the advice of his own colonial bureaucracy as well as white settler opinion and legislated for a modern system of industrial regulation which included legalisation of unions. The two pieces of legislation prepared for this purpose were the Industrial Relations Ordinance and the Industrial Organisations Ordinance. Hasluck claimed that the legislation would allow Papua New Guineans to develop their own system of industrial negotiation. He would "clear a path but let them walk it" (Department of Territories, 1961, p.6). In fact these ordinances have determined much of the subsequent shape of PNG industrial relations. They reversed the previous policy of suppressing dissatisfaction in favour of channelling it into acceptable paths. The former ordinance made provision for Industry Councils, Boards of Inquiry and direct negotiation as well as compulsory conciliation and arbitration. The latter

- Michael Hess teaches in the School of Industrial Relations and Organization Behaviour at the University of New South Wales. James Gissua is a Doctoral student in that School and was formerly Director of PNG's National Tripartite Consultative Council. 
legalised unions and offered them a dubious degree of protection from civil suit (Seddon, 1968). The cost to unions was a series of controls over their structure and operation. The most serious of these were the powers to register and de-register vested in the newly created office of the Industrial Registrar.

The legislation was undoubtedly progressive in that it finally overcame the out-dated situation in which "the very idea of collective bargaining was almost a subversive one" (Rowley, 1968, p.7). Giving workers with little knowledge of industrial organisation the right to freedom of association was, however, a negligible concession. With little possibility of unionism developing in rural areas the new legislation would control plantation workers as completely as the old had. By providing acceptable channels for their grievances, it would deal much better with the dissatisfaction of urban workers. Furthermore, the old forms of control, developed over the years of colonial rule, were no longer politically acceptable internationally and their value within PNG was also being called in doubt by increasingly vocal nationalist sentiment.

The newly legislated industrial relations system was tripartite in nature. Employers with five long established organisations were well prepared for collective negotiations. The Administration had recently elevated its labour office to departmental status and was also well able to represent its viewpoint. There were, however, no unions capable of representing PNG workers in negotiations. It fell to the officers of the new Department of Labour and subsequently the Bureau of Industrial Organisations, which was created especially for the purpose, to 'encourage' the formation of unions to fulfil the tripartite requirements of the industrial relations machinery. On paper they did this very successfully.

Table 1: Registered unions at independence

\begin{tabular}{|c|c|c|c|c|}
\hline Name & $\begin{array}{l}\text { Date } \\
\text { Registered }\end{array}$ & $\begin{array}{l}\text { Type of } \\
\text { Union }\end{array}$ & $\begin{array}{l}1963 \\
\text { M'ship }\end{array}$ & $\begin{array}{l}1974 \\
\text { M'ship }\end{array}$ \\
\hline Lae Workers' Association & $27 / 8 / 63$ & Regional & 963 & 440 \\
\hline Madang District Workers A. & " & " & 349 & 130 \\
\hline Rabaul Workers' Association & $"$ & $"$ & 427 & 350 \\
\hline Public Service Association & $17 / 1 / 64$ & Industry & 10,309 & 15,880 \\
\hline Wewak Workers' Association & $26 / 3 / 64$ & Regional & 336 & 118 \\
\hline Port Moresby Misc. W.U. & $22 / 5 / 64$ & $"$ & 245 & 1,081 \\
\hline Wau-Bulolo Workers' Assoc & $12 / 6 / 64$ & $"$ & 481 & 474 \\
\hline Goroka Workers' Association & $25 / 8 / 64$ & $"$ & 209 & 25 \\
\hline New Ireland District W.A. & $16 / 11 / 64$ & $"$ & 203 & 187 \\
\hline Northern District W.A. & $19 / 2 / 65$ & " & 130 & 123 \\
\hline Police Association & $"$ & Industry & 1,800 & 2,656 \\
\hline Western Highlands District W.A. & $10 / 5 / 65$ & Regional & 124 & 20 \\
\hline Milne Bay District W.A. & $18 / 6 / 65$ & " & 223 & 200 \\
\hline Bank Officers' Association & $16 / 6 / 67$ & Industry & 162 & 205 \\
\hline Uni. of PNG Staff A. & $29 / 9 / 67$ & Staff As. & 160 & 142 \\
\hline Manus District W.A. & $10 / 10 / 67$ & Regional & 225 & 134 \\
\hline Tech. Institute Staff A. & $4 / 1 / 68$ & Staff As. & 86 & 52 \\
\hline Abau District Worker's A. & $4 / 3 / 68$ & Regional & 97 & 350 \\
\hline
\end{tabular}




\begin{tabular}{|c|c|c|c|c|}
\hline Western District W.A. & $25 / 10 / 68$ & $"$ & 102 & 84 \\
\hline B'ville Catholic Teachers' A. & $18 / 11 / 68$ & Staff As. & 305 & 299 \\
\hline Central District Building W.U. & $28 / 1 / 69$ & Industry & 725 & 800 \\
\hline Central District Waterside W.U. & " & $"$ & 277 & 125 \\
\hline Senior Police Officers Guild & $10 / 2 / 69$ & Staff As. & 37 & 49 \\
\hline West Sepik District W.U. & $4 / 7 / 69$ & Regional & 125 & 110 \\
\hline Airline Employee's Association & $4 / 11 / 69$ & Industry & 65 & 160 \\
\hline B/ville Mining Workers' Union & $12 / 12 / 69$ & " & 450 & 800 \\
\hline Gulf District Workers' Association & $13 / 7 / 70$ & Regional & 65 & 160 \\
\hline B'ville General Workers' Union & $21 / 8 / 70$ & & 466 & 800 \\
\hline Air Traffic Officers' Association & $7 / 10 / 70$ & Industry & 83 & 89 \\
\hline Port Moresby Clerical W.U. & $10 / 11 / 70$ & " & 96 & 46 \\
\hline Local Government Workers' A. & $29 / 1 / 71$ & $"$ & 20 & 20 \\
\hline Lombrum Naval Civilian W.A. & $19 / 2 / 71$ & House & 162 & 250 \\
\hline Kainantu Workers Association & $26 / 3 / 71$ & Regional & 55 & 55 \\
\hline PNG Teachers' Association & $1 / 4 / 71$ & Industry & 8,430 & 9,869 \\
\hline Air Hostesses' Association & $18 / 5 / 71$ & " & 175 & 150 \\
\hline Merchant Service Officers' A. & $24 / 9 / 71$ & $"$ & 32 & 31 \\
\hline Central District Transport W.U. & $30 / 3 / 72$ & $"$ & 24 & 24 \\
\hline PNG Nurses' Association & $12 / 12 / 72$ & $"$ & 174 & 148 \\
\hline Lae Stevedoring Union & $"$ & $"$ & 657 & 657 \\
\hline PNG Overseas Seamen's Union & $"$ & $"$ & 28 & 28 \\
\hline Madang Waterside Workers' Union & $"$ & $"$ & 70 & 94 \\
\hline PNG Airpilots' Association & $8 / 8 / 73$ & $"$ & n.a. & 100 \\
\hline Mendi Workers' Association & $13 / 5 / 74$ & Regional & n.a. & 200 \\
\hline Morobe District Rural W.A. & $26 / 7 / 4$ & & n.a. & 50 \\
\hline Aircraft Engineer Association & $15 / 10 / 74$ & Industry & n.a. & n.a. \\
\hline Broadcasting Staff Association & $24 / 1 / 75$ & Staff As. & n.a. & 100 \\
\hline West New Britain Workers A. & " & Regional & n.a. & 23 \\
\hline
\end{tabular}

Abbreviations: D. - District, U. - Union, W. - Workers, A. - Association, n.a. - not available.

Sources: Industrial Registrar, Files 0-001 to 0-052.

Table 1 presents a statistical summary of union development between 1963 when the legislation became effective and 1975 when PNG became independent. In this period 47 unions were registered under the Industrial Organisations Ordinance. Despite this impressive record of creating unions there must be serious doubts about whether they had the ability to be really effective in pursuing their members' industrial interests. Three factors with potential impact on organisational effectiveness are immediately evident. The first is the extremely small size of the unions. Of the 47 registered in 1975 only eight had more than 500 members. The effect of this on the ability of unions to be genuine parties to collective negotiation may be judged by the contemporary estimate that 300 was the absolute minimum membership for financial viability (Martin,1969). The second factor is the general and regional character of union coverage. Half of the registered unions were regionally based general workers' associations. Their notional coverage extended to all workers in their 
region, who were not permanent public servants. In practice these organisations had little chance of developing more than a token presence in the many small and scattered workplaces which such a coverage implied. They tended to be concentrated in one or two workplaces of the major employers of casual labour such as the wharves or Public Works Offices of their regional centres. The third factor of note, revealed in the comparison of average membership with that of 1974 , is that membership was subject to wild fluctuations. Whether this was due to workers' lack of understanding of the "proper" role of unions (Patterson, 1969, p.26), their "unfamiliarity with an association which requires periodic renewal of membership by cash subscription" (Deech, 1976, p.15), or the new organisations' failure to hold on to "'first fervour' recruits" (Plowman, 1978, p.6) such marked instability would clearly have had an adverse effect on the unions' organisational capacity.

Only three of the regional workers' associations have attracted detailed study (Metcalfe, 1968; Stevenson, 1986; Hess, 1982). A common picture emerges from these studies of capable, ambitious leaders establishing unions with enthusiastic worker support but moving quickly on to the national political stage. Deprived of constant contact with these leaders the associations were unable to represent their members in mundane matters. Nor were they able to meet their obligations under the Industrial Organisations Ordinance. Their membership lists were rarely accurate and they often failed to carry out the relatively simple clerical tasks of conducting annual elections and audits. They were not, however, de-registered, but were propped up by the Department of Labour to fulfil, on paper at least, the tripartite requirements of the industrial relations system. Commentators have pointed out that this poor level of union development undermined the machinery's potential for dispute resolution and wage fixing (Isaac, 1968) and have variously blamed the colonial background (Rowley, 1968), workers' lack of education (Bailey, 1970), their "misconceptions" about how unions should operate (Patterson, 1969) and poor leadership (Chapman, 1969). Less attention has been paid to the handful of exceptional organisations which were able to develop both the membership and leadership prerequisites for effective operation within the system of compulsory conciliation and arbitration ((Spaull, 1974; Hess, 1986).

At independence PNG's industrial relations system was a decade old. It operated at several levels and its degree of success varied from level to level. In the workplace it was, with a few notable exceptions, irrelevant. In the public sector only the Public Service Association and the Teachers' Association were organisationally competent. In private industry only the Bougainville unions and the Central District Waterside Workers' Union were able to represent their members in the workplace. A larger number of unions were able to participate in the system at the level of award making through the intervention of absentee leaders. Their industrial action was generally limited to the agreements such leaders made with employers which ensured their members received flow-ons from major awards and periodic minimum wage increases. Few unions were well enough organised to negotiate over a wider range of issues or to deploy the weapons of industrial action in support of their demands. Only at the most general level of wage fixing, where direct union input was limited to the appearance of a few advocates, was the system really successful. In 1972 amendments to the Industrial Relations Ordinance strengthened the role of such 'outside' union leaders by making Minimum Wages Boards the centre piece of the wage fixing system. The minimum urban and rural rates fixed by this tribunal were to have a seminal effect through flow-ons. Unions which chose to participate in the hearings could do so by engaging a competent advocate while those that did not could merely apply to have their awards altered to conform with the new national minimums.

In summary then, the industrial relations system inherited by PNG at independence 
was at its most successful at a bureaucratic level. As a mechanism for articulating and resolving industrial grievances in the workplace it was frustrated by a lack of adequate union organisation.

\section{Trends in Papua New Guinea unionism}

An instructive example of how union weakness continued to inhibit the development of effective industrial relations mechanisms is revealed in the history of PNG's peak union council. This began in the mid-1960s as the Federation of Workers' Associations (FWA) (Hess, 1988). It was set up by a coalition of interests comprising the colonial officers charged with overseeing the operation of the industrial relations system and the emerging national Papua New Guinean politicians, who were the leaders of the small regionally based general workers' associations. For the former it represented an opportunity to enhance the operation of the system by creating a peak union body which would have the educated leadership and resources they saw as a necessary prerequisite to the operation of the tripartite industrial relations machinery. For the latter it was a chance to strut the developing national political stage.

Despite continued support from the Department of Labour and occasional interest from the Australian Council of Trade Unions the FWA achieved only an ephemeral existence through the late 1960 s. By the early 1970 s it was strong enough to act as a channel for wage claims but had no genuine capacity for action outside the industrial relations machinery (Langmore, 1973. p.169). For the politicians and Department of Labour officials who had supported its establishment this was not necessarily a bad outcome. The politicians had gained a national institution which they could be seen to lead and the industrial relations bureaucrats gained an organisation which enhanced the operation of the machinery they were called upon to administer. While neither would need to call upon it very often, the Federation provided for both groups a vehicle to transport industrial issues to the national level at which they were most comfortable. The lack of genuine worker participation in the organisation also meant that it was unlikely to prove troublesome to either the politicians or the bureaucrats. It was, however, of very little real use to the workers. Its utility for the industrial relations system was limited to preserving the fiction of tripartism, when in fact it did not genuinely represent ordinary workers at all.

In 1973 the organisation began to change as it came under the influence of younger PANGU Party activists, who were at this time radical nationalists. For the next decade PNG's peak union council was dominated by Tony Ila. Ila was the Member of Parliament for Lae and a PANGU stalwart. He began by changing the name of the FWA to the Trade Union Congress (PNGTUC) and moved its headquarters to Lae (Hess, 1992). While Ila did enhance the organisation's capacity for action, his principal motivation appears to have been political rather than industrial. Certainly the PNGTUC was much more active in his own electorate than anywhere else!

As Ila moved, along with the PANGU Party, into government his politics became more conservative. He rejected overtures from the left-wing World Federation of Trade Unions and led PNG unionism into a close international association with the rival, anti-communist International Confederation of Free Trade Unions. This anti-communist agenda was further strengthened by his desire to work closely with the American Federation 
of Labor-Congress of Industrial Organizations international aid agency the America-Asia Free Labor Institute. This organisation had a quite open agenda of supporting those unions in the Asia-Pacific region which would adopt a staunchly anti-communist position. Despite the paranoid statements of Australian 'intelligence' authorities there was no communist political influence in PNG. Ila was nonetheless able to use the Americans as a source of finance. With their aid he built a PNGTUC office and workers' club complex and a medical centre in the suburbs of Lae. He also, perhaps because of the United States influence, sought to take the PNGTUC along the road of business unionism with proposals ranging from ownership of food processing companies to operating a travel agency and a five star hotel. None of these proposals came to anything but they used up a great deal of time and energy. They were allied with Ila's rise to national political prominence and after he became Minister for Labour in the late 1970s the confusion between union and business activity became even more pronounced. For long periods the PNGTUC's only activity was in this area of business schemes, while worker's wages and conditions were neglected. The best that can be said of Ila's dual role as Minister for Labour and President of the PNGTUC is that his lack of differentiation, in undertaking the two apparently contradictory roles, made it possible for department officers to directly aid unions. The fact was, naturally enough, that this aid was directed towards enhancing the operation of the industrial relations system rather than pursuing the interests of the workers. It also reduced the unions to dependence on the government officials.

There is, however, little evidence that any large number of PNG unionists thought that this was in any way improper. Indeed there was considerable popular support for Ila's leadership during this period in which he was seen by many workers as their best hope. By the early 1980s the situation had changed. PANGU was out of government and Ila's hold over the PNGTUC affiliates, which had been sustained by the distribution of government financed gifts, such as conference trips and study tours, lapsed. The more militant and effective Port Moresby unions allied with the Bougainville Mine Workers' Union moved to have Ila replaced and Henry Moses of the BMWU became PNGTUC president in 1983. In order to understand the significance of these events it is necessary to make a brief detour from the history of the peak council and look at some individual unions which were operating successfully.

The PNGTUC represented only private sector unions and its main strength came from the weak regionally based workers' associations. These were not, however, PNG's only private sector unions. Two organisations which had chosen a different path and had proven more effective were the BMWU and the Central District Waterside Workers' Union (CDWWU). The former was based at Bougainville Copper Limited's gigantic copper mine at Panguna. It covered all wages employees and was led by the late Henry Moses, who was also a leader of the landowning clan at Panguna. The BMWU may have been kick started in its attempts to organise the PNG workforce by the example of industrial negotiation set by militant Australian unionists during the mine's construction phase. By the mid 1970s it had developed into a formidable union, which was very much a legitimate part of both BCL's operation and life at Panguna and Arawa.

The CDWWU had followed a more torturous path and this has been described at length elsewhere (Hess,1986). Very briefly it grew out of the ruins of the Port Moresby Workers' Association which had promised much to urban workers but had collapsed in the late 1960s. The waterside workers decided that they would be better off in their own union. Their first leader was an aspiring local politician, Gavera Rea. When he went into parliament in the 1972 elections he introduced a young Australian, Reg McAlister, to the waterside 
workers as a possible replacement. Earlier in the year, McAlister had created a public sensation when he crossed the lines of race to become an activist in the Clerical and Shop Assistant's Union.

McAlister was just the leader Port Moresby's waterside workers were looking for. His willingness to take militant action matched their mood. He also brought to them an understanding of industrial tactics, which had previously been lacking. The CDWWU embarked on a campaign to reform the casual system of employment. A major strike in 1972 caused the government to create a Board of Inquiry into the system of employment on Port Moresby's waterfront. Assisted by the advocacy of Norm Docker of the Australian Waterside Workers' Federation (WWF), the union used the inquiry as part of a broad campaign. With further industrial action and a well argued case it achieved a major victory. The casual system of employment was replaced by a register of watersiders, a roster to equalise work opportunities and the payment of attendance money for those not required for work on a particular day. The employers' rights to both hire and fire as they wished were severely restricted with major increases in wage rates and improvements in working conditions also being achieved.

No other PNG union had or has been able to achieve so much. Certainly the time was favourable to the union. With the Whitlam government forcing the pace on the granting of independence and the upsurge of nationalist feeling of the period, tribunals of Papua New Guinean officials were ready to hear the case of a union of their fellow countrymen struggling against the outdated colonial management practices of foreign companies. But no other union was able to take anything like the advantage of this situation and much credit must go to McAlister and the CDWWU officials of this period and to the WWF, which provided strong logistical support through Norm Docker's advocacy.

In 1982 the CDWWU crowned a decade of achievement with the amalgamation of maritime unions in Port Moresby, Lae, Rabaul and Madang to form the PNG Waterside Workers' and Seamen's Union (WWSU). Its registration was strongly opposed by employers and their parliamentary allies but the experience of the CDWWU officials in using the industrial relations machinery enabled the unionists to prevail. The WWSU was the first and is to date PNG's only national organisation of private sector workers.

In the public sector both the Public Employees Association (PEA) and the PNG Teachers' Association (PNGTA) inherited some useful situations from the unions of colonial officials they replaced. The early history of the PNGTA has been described by an Australian unionist, who was involved in assistance to the organisation in the early 1970s (Spaull, 1974). It developed out of colonial structures, which represented Australian teachers in TPNG. As the teaching service became increasingly 'localised' Papua New Guinean teachers attempted to form their own organisations. The first, the Local Teachers Association, collapsed when its leader, Vincent Eri, was sent on a long overseas trip by the colonial Administration. The PNGTA was, however, able to overcome the problems of dependence upon a single individual and during the early 1970 s, as PNG moved towards full independence it emerged as a well resourced and moderately successful union. The PEA evolved even more directly from its colonial predecessor. In the 1970 s, when it was still dominated by Australian colonial officials, it had embarked upon demands for equal pay for PNG public servants doing the same jobs as their white colleagues. At the same time it was heavily involved in negotiating retrenchment packages for the colonial officers themselves.

Unfortunately for PNG unionism the PEA and PNGTA continued to stand aloof from the PNGTUC. The BMWU and the WWSU, however, became important factors in reforming 
the moribund peak council. In 1985 this process received a huge boost with a major assistance package from the ICFTU-Asia Pacific Regional Office. They agreed to fund a three year organisational program under which it was intended that the PNGTUC become a viable and independent organisation. The program included the secondment of a full-time officer for a year to 'monitor' progress and the establishment of a properly staffed office. With the appointment of Lawrence Titimur as General Secretary, John Paska as Research Officer and with Reg McAlister acting as Assistant Secretary, the PNGTUC began to look like a genuine national union centre.

So impressive were the gains under the new leadership that by 1987 both the PEA and the PNGTA had affiliated. An indication of the growth in support can be seen in Table 2. Between 1985 and 1989 the PNGTUC went from representing 12 unions with a total membership of 17,500 to having 40 affiliates with a total claimed membership of 70,000 . This gave the PNGTUC the right to claim to represent the interests of 33 per cent of the total workforce. At last PNG seemed to have a real union structure, which would bring worker views into the economic decision making process in a genuine way.

Table 2: PNGTUC affiliation, 1985-1989

year affiliates members \% unions \% workforce

$\begin{array}{rrrrr}1985 & 12 & 17,500 & 22 \% & 8 \% \\ 1988 & 28 & 60,000 & 75 \% & 28 \% \\ 1989 & 40 & 70,000 & 82 \% & 33 \%\end{array}$

Source: PNGTUC, Secretariat and activities report, December 1989.

That this unity was fragile became apparent in the following year when first the PEA and then the PNGTA refused to pay affiliation fees on the ground that the PNGTUC was not doing enough for their members. In fact the motives were political. The large public sector unions had expected, with some reason, that they would become the dominant forces in the reformed PNGTUC. Titimur had resisted this as an infringement of his own authority. The PEA, in particular, had an equally determined leader in Napoleon Liosi, who felt that he should have a greater role in PNGTUC affairs than Titimur was allowing.

In 1991 the argument was still going on with cooler heads on both sides trying to establish a formula by which the large public sector unions could bring their resources into the PNGTUC without completely dominating it. The future success of the organisation depends heavily upon the outcome.

A final trend worth noting in the recent development of PNG unions is the establishment of a Federation of Airline Workers' Unions. This was achieved in 1991 and was based on a working relationship which had been developed between the National Union of Airline Employees and other unions in the industry covering stewards, engineers and air traffic controllers. The pilots' union has remained outside the Federation but has cooperated with it in some areas. 


\section{Industrial disputation in the $1980 \mathrm{~s}$}

In general the levels of industrial disputes in PNG have been low. The statistical picture for 1985 is fairly typical. Of 33 strikes reported by the Department of Labour and Employment, 22 occurred in primary production; 12 lasted less than one day and 18 less than two days; 20 were settled by voluntary conciliation through a third party, usually an officer of the Department (Department of Labour, 1986). The majority of strikes, then, occurred on plantations where unions are either non-existent or poorly organised and were of short duration. This points to their character as protest actions designed to attract the attention of someone who could address the workers' grievances. That such strikes were generally settled by conciliation by officers of the Department of Labour adds to the view that their purpose was essentially to get the industrial relations machinery moving on an issue which workers had no other way of addressing.

There have, however, been exceptions and it is the few longer disputes, which occurred as part of an industrial campaign and went through the full gamut of industrial dispute mechanisms which tell us most about the operation of the system itself. Here we wish to present brief accounts of two such disputes, which reveal some fundamental issues in the effectiveness of PNG's industrial relations processes.

\section{The 1988 Ok Tedi dispute}

The Ok Tedi Mining Limited (OTML) operates a gold and copper mine at Mt. Fubilan in the Star Mountains of the Western Province in PNG. Since 1985 the mine has been managed by Australia's Broken Hill Proprietary Limited (BHP), which is the major partner in a consortium including German and US interests. This mine is located in one of the more underdeveloped and remote parts of the country. The area was first contacted by government officials in 1963 and when mining occurred in 1982 no real 'development' had taken place. By 1988 , however, the mining township of Tabubil had a population of 3,500, about 50 per cent of whom were mine employees and their dependents, with the other 50 per cent being made up of sub-contractors and government personnel.

Most PNG blue collar workers were members of the Ok Tedi Mining Construction and General Workers Union (GWU). In 1988, the GWU had about 1,400 members. An industrial agreement, which had been re-negotiated over the years, provided the members with some of the most attractive conditions of employment in the country. There were several issues, however, which had remained unaddressed in this award and had the potential for causing major disputes.

The first was housing. Successive negotiations with the company over the years had not produced any significant results. The limited number of houses that were available had all been allocated to members of staff according to an allocation policy, which favoured the higher levels of management and therefore the foreign employees. For many union members the lack of housing had meant years of separation from their families. OTML refused to build more houses for three reasons. Firstly, world copper prices had declined to an extent where the repayment of its loans had become difficult to maintain while at the same time interests on its loans increased. Secondly, the banks would not approve any more loans in view of its tight financial situation. Thirdly, even if there were funds available, it might be 
difficult to build any more houses given the local geography.

Another issue of concern to the union related to training and localisation. All other private sector firms in PNG which employ foreign labour, are required every three years to provide progressive reports to the Department of Labour and Employment and state when particular positions could be localised. On numerous occasions, the union accused OTML of failing to fulfil its training and localisation plans thereby unduly limiting promotional opportunities for union members.

A final immediate issue in 1988 was the sudden introduction of a three shift system to increase production. The union blamed the Executive Manager (Mines), Rick Gazzard, and the Employee Relations Manager, Bebea Konie for lack of consultation in the changes and demanded the termination of these two members of management. It was this termination demand plus the long running issues of housing and localisation, which triggered one of the most difficult disputes PNG's industrial relations system has had to face.

The strike commenced with 70 operators of heavy equipment at the mine pit walking out for three days on 18 July 1988 . These workers were the most skilled of the PNG workforce and were employed alongside foreign workers brought into the country on account of their skills. They were also experienced miners with an understanding of industrial issues and action derived from work on mines such as Bougainville Copper Limited's Panguna operation. The operators struck without the company or the union executive knowing and described their action as a protest against the 'dictatorial' approach by Gazzard in attempting to control their work routines right down to the minute details. They also questioned management about the hasty manner by which major changes, such as the second shift, had been introduced. Demands for more housing as well as for better promotional opportunities were also raised. Since there had been neither the prescribed secret ballot nor any involvement of the union's elected officials the strike was considered illegal by the Department of Labour and Employment.

When the union executive agreed to take up the issues with the company the operators returned to work. The union-management negotiations between 22 July and 17 August failed to reach an agreement. On the one hand, the union insisted that a PNG national Kipling Uiari, Executive Manager (Public Affairs) lead the management team in place of the expatriate Executive Manager (Personnel), Warren Pearson. On the other hand, the company adopted a non-negotiable stance on the termination issue claiming absolute management prerogative to "hire and fire". Some progress was made on the issue of housing with the company agreeing to build 20 new houses but this fell well short of the union's demand for 500. The issue of localisation had been transformed into a question of reclassification but no progress was made on this.

Both sides realised the inevitability of further industrial action. On 1 August Uiari asked the Department of Labour and Employment to intervene. While the union requested that the Industrial Registrar conduct a secret ballot on the question of further strike action, the local MP, Bob Bubec, a former OTML employee himself also got involved, meeting with the union executive on 2 August. The ballot overwhelmingly endorsed the proposed strike, which took place between 18 and 30 August. Union leaders, company security personnel and the 20 local police maintained order and the strike was peaceful. However, it achieved little for the union. The company's response to its demand on termination did not change while no progress was made on the housing and reclassification issues.

During the strike major weaknesses in the industrial relations machinery were evident. The major one was that the union executive had no strategic plan. It seemed unaware of the implications of its actions, did not really want the strike and had no facilities for supporting 
members during a long dispute. The Department of Labour and Employment was equally unprepared. A compulsory conference and the establishment of a board of inquiry had been considered but a number of problems prevented use of one of these options. Firstly, the termination demand was considered a non-industrial matter within the meaning of the Industrial Organisations Act and therefore, could not be dealt with using the formal industrial relations machinery. The demand had been also considered as interfering with one of the fundamental rights of management prerogatives. Secondly, both parties appeared not to favour arbitration as a suitable option. Despite the fact that hardly any consistent approach had been adopted by way of negotiations between the parties, both expressed optimism about a settlement through negotiations. Thirdly, the company had been reluctant to accept the idea of a board of inquiry with wide powers to investigate its industrial and personnel policies.

The strikers returned to work on 31 August on the understanding that further negotiations had been arranged for 14 September in Port Moresby in which the company would produce a detailed proposal on housing and reclassification while the termination demand would be dealt with by a board of inquiry. The company initially requested a five day delay to the scheduled meeting and then failed to produce its detailed proposals. When the company did produce its plan on 21 September it included an increase to 230 new houses plus a marginal lowering of the eligibility classification. The union took the delays as an indication of lack of serious intent on the company's part and rejected the offer. It did accept the Department's suggestion that a board of inquiry be established but asked that it not only investigate the termination demand but also look at the entire operations of the company with particular attention to labour and employment matters.

On 22 September unexpected industrial action broke out and virtually destroyed any chance of the parties arriving at a settlement through the conciliation process. In the early hours of that morning, a number of front end loaders and semi-trailers were used by the striking workers to close all roads and the airport. Trenches were dug across the main roads into the town, barricades were erected and the main telecommunication cables were cut. Liquor outlets were broken into and the hotel building was vandalised. Company vehicles were overturned while the golf and hash house harriers clubs, which were the preserves of the largely white expatriate workforce were burnt down. Threats were made against the company's main office complex, commonly known as the "White House" and some expatriates complained of being physically harassed for having crossed the barricades (Niugini Nius, 23 September 1988).

The government's reaction was predictable. The first contingent of riot police arrived at Tabubil on 23 September and within three days there were 300 policemen and Defence Force soldiers in the town. A five member team of national politicians and senior bureaucrats arrived at Tabubil from Port Moresby on September 26 to investigate the situation. The team, headed by Father John Momis, Minister for Decentralisation, met with all the parties and soon after, endorsed the proposition that a board of inquiry be established immediately to investigate the dispute and submit its report to the National Executive Council. The company continued to reject the suggestion that the board investigate all aspects of its operations but no longer had any choice. A compulsory conference was convened on 30 September to endorse the option for a board of inquiry and formally request the Department of Labour and Employment to arrange for the board to be established. The strikers returned to work on 1 October and the union accepted the company's offer in respect to housing.

The three main issues facing the board of inquiry were the termination demand, housing and training and localisation. The board wound up its formal hearings on 28 October 
and presented its report to the Minister on 18 November. The board's report contained 38 recommendations and also identified certain weaknesses within the company, the union, the Departments of Labour and Employment and Minerals and Energy. These organisations were directed by the board to implement relevant recommendations which pertain to their special areas of responsibility. In respect of the termination demand, the board acknowledged the technical qualifications and expertise of Gazzard but concluded that "he has not been oriented to the proper and appropriate management style and has an attitude intolerant to other's ideas" (Board of Inquiry, 1988, p.98). On this basis, the board recommended that in the event of any further industrial unrest resulting from his behaviour, BHP management should have him replaced. In the case of Konie, the board observed how he had been handicapped by "the expatriate dominated Personnel management" and also how he had been "bypassed by Operations management" which prevented him from performing his functions effectively. The board recommended that the Employee Relations Manager have the discretion of direct access to the General Manager over important industrial relations matters. The board also recognised the need for adequate manpower and budgetary support for the efficient operations of the Employee Relations Department. Furthermore, the board recommended that both Gazzard and Konie formally apologise to the workers for their roles which partly precipitated the series of industrial actions.

The board merely endorsed the new Housing Agreement arrived at between the parties in October but emphasised the need to upgrade female accommodation and recreational amenities and the introduction of a low cost home ownership scheme for employees below grade 6. While the board endorsed the October agreement on a 10 grade structure, it identified the lack of progress and implementation of training and localisation programmes to have been a major impediment. The board recommended that no further work-permits be granted to the company by the Department of Labour and Employment until a number of necessary adjustments were made within the company to ensure training and localisation programmes were implemented.

The dispute which had such a spectacular beginning and involved major State intervention - including the deployment of riot police - was effectively ended by the almost mundane proceedings of the Board of Inquiry. The issue this raises is: if the issues were resolvable by such an orderly means, why was it necessary for the dispute to take such a confrontationary and costly course to begin with? The simple answer offered by the General Secretary of the PNGTUC was that, "without that action the issues would never have been addressed" (Interview, Titimur). At the very least, the fact that PNG's leading union official had such an attitude indicates that the industrial relations system is in some difficulty. If management and the industrial relations bureaucracy require the erection of barricades, arson and looting to take place before they move on worker grievances there is good reason to believe that the nation's labour relations are in deep trouble.

\section{The 1987 Air Niugini dispute}

By contrast the 1987 Air Niugini dispute was a dull affair. There were no strikes, no riotous behaviour and no police intervention. Nonetheless the course of the dispute reveals some of the same weaknesses in industrial relations as were evident at Ok Tedi.

Air Niugini is PNG's national airline and has been in operation since 1976, a year after national independence. It controls a majority of the domestic market and remains the 
only PNG airline permitted to operate international routes. Despite this market prominence, Air Niugini has faced mounting criticism. Declining profits in the early 1980 s led to a series of management reviews by foreign experts and its own management had been alleged to be inefficient with scandals such as a major fraud uncovered in 1988, where it was estimated that between $\$ 200,000$ and $\$ 300,000$ had been syphoned from Air Niugini every year since 1984 (Post Courier, 24 June 1988) adding to management woes.

While Air Niugini management had been desperately trying to identify ways to make the airline a profitable organisation, the growth of trade union activity in the mid-1980s posed another challenge. Up to 1982 , all industrial relations functions had been under the Department of Personnel but by 1985 it became necessary for management to create an Industrial Relations Department. Whereas most PNG employers face enterprise or company unions Air Niugini's employees were organised into three craft and one general union covering pilots, engineers, flight attendants and general employees, all with their own industrial awards. The largest of these unions, the National Airline Employees Association (NAEA), was formed in 1986 as a result of an amalgamation of the National Salaried Officers' Association and the National Graded Officers' Association, to cover Air Niugini's administrative and other non-engineering ground staff. In 1987 the NAEA took its organisation a step further with the appointment of Reg McAlister as its full-time General Secretary. McAlister's outstanding record in PNG unionism has already been mentioned. He brought to the NAEA a knowledge of industrial tactics based on almost two decades of successful union leadership.

At this time Air Niugini's Industrial Relations Manager was Lawrence Pukali. Despite his five years in the job and his legal training, Pukali seems to have been ill equipped to deal with an increasingly militant union. In 1987, Air Niugini had recruited additional industrial relations staff as a direct response to the growth of its unions and a perceived likelihood of an increase in industrial disputation. The truth of this perception may be seen in the fact that in the three years 1985-7 the company had experienced only 20 disputes, whereas in the two years 1988-89 it reported 47 disputes (Department of Labour, 1989).

Under Air Niugini's unitarist management approach any employee found to infringe management policies had to be terminated so that in the long run only loyal and committed employees would remain. Once the workforce achieved some measure of industrial representation such a policy was bound to lead to a rapid escalation in disputes. An example of the type of dispute this situation created may be seen in the 1987 case of Peter Simbago, demoted for negligence. It just happened that Simbago was the NEAE's president and there was no way that an increasingly organised union was going to accept that this was not an act of victimisation. It took two years before this case was settled at arbitration and during this lengthy delay the management tactic of reviewing decisions and not seeking a settlement gave the newly active unionists of the NAEA ample scope for developing a hostile attitude on the basis that they might be next.

The details of the case reveal that even in the public sector PNG management has a long way to go before it achieves a cooperative relationship with its workforce. In 1987, Peter Simbago was Passenger Handling Supervisor, a position he had held for over 18 months after nine years with Air Niugini. His duties included:

- controlling check-in counters

- ensuring check-in traffic flows smoothly

- ensuring all international transit passengers have proper visas

- ensuring proper collection of excess baggage fees and 
- responsibility for two senior and 16 junior staff.

He had been President of NAEA for about eight months and had been re-elected to serve for a second term. He was part of the movement which was revitalising the union and had brought McAlister into it's leadership to give it the industrial experience the rank and file officials lacked.

Simbago's demotion arose from his use of supervisory discretion in respect of a traffic officer, who had breached company practice in the use of concessional travel to return to his home province for a short period. The officer had arranged his leave correctly but had travelled on a non-approved flight without a ticket. He had done this after previously arranging with Simbago, his supervisor, that he would in fact travel on an approved flight. Simbago was unaware that the officer had altered his plans. Under the circumstances, Simbago resorted to his discretionary powers, a privilege bestowed on supervisors which he had not used for sometime. He picked-up the officer's pay, paid for his return tickets and arranged for his travel back to Port Moresby. In view of his use of supervisor's discretion, he was content about his actions and considered it not necessary to report the traffic officer's infringement of policy.

Air Niugini suspended Simbago the day after the officer's return and demoted him from the position of Passenger Handling Supervisor Grade 7.2 to Traffic Officer Grade 3.5 a week later (ANG, 1987). The decision by Air Niugini to have Simbago demoted had been the result of an investigation conducted by the Industrial Relations Department. The investigation report concluded that Simbago had condoned the officer's actions when he collected his pay, paid for his fares and airline tickets and failed to report the matter to the Airport Manager. However, the union disputed the findings of the investigators on the basis that Simbago had never been provided an opportunity to submit his views.

It took ten months before the union notified the Department of Labour and Employment of the existence of an industrial dispute. The delay was apparently due to the union's waiting for management to implement its own stated procedures. Official company policy was that demotions were to be reviewed every three to six months with reinstatements to former positions based on performance. In this case, Air Niugini had not carried out such a review for 11 months and Simbago had already received excellent reports from his superiors in respect of a number of higher duties he had performed in acting capacities. In the circumstances management's unwillingness to reinstate Simbago added to union suspicions about the motive for his demotion.

All conciliation attempts failed and on July 27, 1989 the Secretary of the Department of Labour and Employment recommended to the Minister the establishment of an arbitration tribunal for a decision on the dispute. The tribunal's terms of reference had been "to concern itself with the justification of the demotion of Simbago with a view to have him reinstated or otherwise" (Department of Labour, 1989). The union's submission rested on two major points. Firstly, in response to Air Niugini's argument about Simbago having condoned the officer's actions, the union argued that he had been unaware of the change of plan which gave rise to the infringements and that he had used his discretion to up-hold Air Niugini policy. Secondly, the union argued that Air Niugini had breached its own policy about reviews on demotion cases in failing to review Simbago's case after three and six months, particularly when all the reports about his performances appeared to have been excellent. Furthermore, Air Niugini had failed to provide any justification as to why the review had never taken place. The thrust of Air Niugini's submission was that Simbago had breached a number of policies. These breaches included his failure to report to his superiors, boarding of an Air Niugini aircraft without a ticket and ignorance of safety standards. Although Simbago had not been 
personally involved in the alleged breaches, these accusations were made on the basis that he had condoned the officer's actions in failing to report them. In respect of the failure to review Simbago's demotion, the company argued that it was giving Simbago reasonable time to prove himself before a review was made.

In its assessment, the tribunal considered Air Niugini's submission to lack substance. Its decision was that Simbago was to be reinstated to his former position as Supervisor Passenger Handling and was to be compensated financially for the period of his demotion and any other monetary benefits that might be owing to him. Air Niugini responded with a formal objection claiming that the tribunal's determination was "unfair, biased and completely wrong". The Department of Labour and Employment responded and advised Air Niugini to seek a judicial review at the National Court if it strongly felt that the tribunal's decision had been a serious miscarriage of justice. Air Niugini lodged with the National Court an appeal but this was later withdrawn soon after Simbago resigned.

As with the Ok Tedi dispute, the origin of the problem here lay in the lack of cooperative relations between the management and its workforce. That an employee of such standing would be treated as cavalierly as Simbago was is particularly incredible in view of the lack of experienced and skilled workers in the PNG labour market. Almost certainly management philosophy and Simbago's involvement in an increasingly militant union were the motives behind the particularly harsh action. As with the Ok Tedi dispute the ease with which the dispute was settled once the industrial relations machinery was set in motion points to the need for parties to have quicker access to the formal dispute settlement mechanisms.

\section{Conclusion}

This paper has looked at the development of PNG's industrial relations system and has provided brief details of a couple of examples of its recent operation. The purpose of this has been to highlight some of the difficulties facing the operation of the system. A major deficiency which emerges is the lack of attention to industrial relations in the management of enterprises. The disputes at Ok Tedi and Air Niugini simply should not have occurred and there is good reason to believe that they would not have occurred if industrial relations management in these enterprises had been efficient. The solution seems to have three parts. The first part clearly lies in having systematically trained industrial relations officers. Even the best training, however, will not overcome a management philosophy which neglects industrial relations and prevents industrial relations management from doing its job properly. The second part of the solution relates to unions and their operation. With a couple of exceptions PNG has not developed unions capable of representing their members' interests. If the Ok Tedi General Workers' Union had done its job efficiently the operators would not have needed to take wildcat action to draw attention to their grievances. The final part of the solution is to give disputants easy and rapid access to the industrial dispute settlement mechanisms.

None of these solutions are without cost. In particular the formal dispute machinery suffers greatly from under staffing and under resourcing. In the long run, however, the cost of unnecessary industrial disputes is likely to be much greater. 


\section{References}

ANG (1987), Air Niugini File, IRM 87/365, 25/8/87.

Bailey, B. (1970), Reflections on Education in Workers' Associations in Papua New Guinea, Industrial Review, 8(2): 24-29.

Board of Inquiry (1988), Report on the Ok Tedi Dispute, Boroko, Department of Labour and Employment.

Chapman, T. (1969), A Need for Leadership, New Guinea and Australia, the Pacific and South-East Asia, 4(1): 26-34.

Deech, F. (1976), Trade Unions in Papua New Guinea, Yagl-Ambu, 3(1): 15.

Department of Labour (1986), Pocket Book of Labour Statistics, Boroko.

Department of Labour (1989), Tribunal Findings on Air Niugini Dispute, Ref 14-11-1.

Department of Territories (1961), Speech by the Minister, Canberra, Government Printer.

Gammage, B. (1975), The Rabaul Strike, 1929, The Journal of Pacific History, 10(3-4): 3-29.

Hess, M. (1982), The Formation and Collapse of the Milne Bay District Workers' Association, M.A. thesis, University of Papua New Guinea.

Hess, M. (1983), "In the long run......": Australian Colonial Labour Policy in the Territory of Papua and New Guinea, Journal of Industrial Relations, 25(1): 51-67.

Hess, M. (1986), Unions and Economic Development: A Papua New Guinean Case, Ph.D. thesis, University of New South Wales.

Hess, M. (1988), PNG's First Peak Union Council: Creating Unions to Fill a Bureaucratic need, Australian Journal of Politics and History, 34(1): 28-36.

Interview, with Lawrence Titimur, General Secretary, PNG Trade Union Congress, Port Moresby, 30/5/90.

Isaac, J.E. (1968), Machinery for Fixing Wages in a Developing Economy, Industrial Review, 7(1): 5-22.

Langmore, J.V. (1973), Labour Relations in Papua New Guinea, 1970-2, Journal of Industrial Relations, 15(2): 158-174.

Martin, R.M. (1969), Tribesmen into Trade Unionists: the African Experience and the Papua New Guinea Prospect, Journal of Industrial Relations, 11(2):125-172.

Metcalfe, P. (1968), Port Moresby's Papuan Workers and their Association, M.A. thesis, University of Auckland. 
Niugini Nius (1988).

Patterson, J. (1969), New Guinea's Trade Unions: When Workers Don't Know What They Want, New Guinea and Australia, the Pacific and South-East Asia, 4(1): 26.-34.

Plowman, D. (1978), Trade Unions in Papua New Guinea: Progress, Problems and Prospects, Industrial Relations Research Centre, University of New South Wales, Working paper 27.

Rowley, C.D. (1968), The Social Background to Industrial Relations in Papua New Guinea, Paper presented at the Seminar on Industrial Relations in a Developing Economy, University of Papua New Guinea, 25/10/68.

Seddon, N. (1968), Legal Problems Facing Trade Unions in Papua New Guinea, Melanesian Law Journal, 3(10): 103-118.

Spaull, A. (1974), The Papua New Guinea Teachers' Association - a Successful Venture in Whitecollar Unionism, Journal of Industrial Relations, 17(1): 72-83.

Stevenson, M. (1986), Wokmani: work, money and discontent in Melanesia, Sydney, Oceania Publications.

Willis, I. (1970), Rabaul's 1929 Strike, New Guinea and Australia, the Pacific and South East Asia, 5(3): 6-24. 